\title{
Use of the checkerboard DNA-DNA hybridization technique for bacteria detection in Aedes aegypti (Diptera:Culicidae) (L.)
}

Analiz de Oliveira Gaio ${ }^{1}$, Rivea CC Rodrigues ${ }^{1}$, Cássio do Nascimento ${ }^{2}$, Nagila FC Secundino ${ }^{3}$, Francisco JA Lemos ${ }^{1}$, Paulo FP Pimenta ${ }^{3}$ and Nadia Monesi ${ }^{4^{*}}$

\begin{abstract}
Background: Bacteria associated with insects can have a substantial impact on the biology and life cycle of their host. The checkerboard DNA-DNA hybridization technique is a semi-quantitative technique that has been previously employed in odontology to detect and quantify a variety of bacterial species in dental samples. Here we tested the applicability of the checkerboard DNA-DNA hybridization technique to detect the presence of Aedes aegypti-associated bacterial species in larvae, pupae and adults of A. aegypti.
\end{abstract}

Findings: Using the checkerboard DNA-DNA hybridization technique we could detect and estimate the number of four bacterial species in total DNA samples extracted from A. aegypti single whole individuals and midguts. A. aegypti associated bacterial species were also detected in the midgut of four other insect species, Lutzomyia longipalpis, Drosophila melanogaster, Bradysia hygida and Apis mellifera.

Conclusions: Our results demonstrate that the checkerboard DNA-DNA hybridization technique can be employed to study the microbiota composition of mosquitoes. The method has the sensitivity to detect bacteria in single individuals, as well as in a single organ, and therefore can be employed to evaluate the differences in bacterial counts amongst individuals in a given mosquito population. We suggest that the checkerboard DNA-DNA hybridization technique is a straightforward technique that can be widely used for the characterization of the microbiota in mosquito populations.

Keywords: Checkerboard DNA-DNA hybridization, Aedes aegypti, bacteria

\section{Findings}

The identification of bacteria in mosquito guts has relied on both culture-dependent and culture-independent techniques [1-3]. Molecular techniques for bacterial identification have received particular attention because they are more rapid than traditional culture methods and in addition can detect bacteria that cannot be cultured. Culture independent methods have mainly been based on the amplification of the 16S rRNA genes by PCR, followed by the identification of the amplified genes through nucleotide sequence comparisons [4].

\footnotetext{
* Correspondence: namonesi@fcfrp.usp.br

${ }^{4}$ Departamento de Análises Clínicas, Toxicológicas e Bromatológicas, Faculdade de Ciências Farmacêuticas de Ribeirão Preto - USP, Av. do Café s/ n, Monte Alegre, 14040-903, Ribeirão Preto, SP, Brazil

Full list of author information is available at the end of the article
}

The checkerboard DNA-DNA hybridization technique [5-8] is a semi-quantitative technique that has been extensively employed in odontology to detect and quantify a variety of bacterial species in dental samples and allows the simultaneous analysis of a large number of DNA samples against a range of DNA probes from different bacterial species on a single support membrane [8]. Here we have tested if this technique is suitable to detect and estimate the number of bacteria in total DNA samples extracted from both whole Aedes aegypti and from dissected $A$. aegypti midguts. In addition, we have also tested if we could detect and estimate the numbers of $A$. aegypti midgut-associated bacteria species in the midgut of other insect species.

In our experiments we employed a modified version [9] of the original DNA-DNA hybridization technique [8]

\section{Biomed Central}

(c) 2011 Gaio et al; licensee BioMed Central Ltd. This is an Open Access article distributed under the terms of the Creative Commons Attribution License (http://creativecommons.org/licenses/by/2.0), which permits unrestricted use, distribution, and reproduction in any medium, provided the original work is properly cited. 
(Additional file 1). As probes we used whole genomic DNA extracted from four bacterial species. Serratia $s p$. (FJ372764), Asaia sp. (FJ372770) and Klebsiella sp. (FJ372760) were isolated from laboratory-bred $A$. aegypti [1,2]. Chryseobacterium sp. (EU169680.1) was isolated from wild-caught $A$. aegypti.

The results obtained after the hybridization of the phosphatase alkaline-labeled bacterial probes with defined amounts of total genomic DNA extracted from each bacterial species are shown in Figure 1. As can be observed, signals of increasing intensity are observed after the hybridization of defined amounts of the Asaia sp. and Serratia $s p$. probes with DNA amounts equivalent to $1 \times 10^{5}, 5 \times$ $10^{5}$ and $1 \times 10^{6}$ cells of these two species (Figure $1 \mathrm{~A}$ ). Similar results are observed after the hybridization of the Klebsiella sp. and Chryseobacterium sp. probes with DNA amounts equivalent to $1 \times 10^{5}, 5 \times 10^{5}, 1 \times 10^{6}$ and $5 \times$ $10^{6}$ cells of these two species (Figure 1B). Together, these results reveal that the intensity of the signals is proportional to the amounts of DNA immobilized on the membranes, and further show that the genomic probes are specific and only detect the corresponding genomic DNAs. The sensitivity of our protocol, which enabled the detection of DNA amounts ranging from $10^{5}$ to $10^{6}$ cells, is similar to that described both in the original checkerboard DNA-DNA hybridization protocol [8] and in the modified versions $[5,9]$.
To test if this technique could detect the presence of bacterial species in A. aegypti samples, a membrane containing total genomic DNA extracted from single whole fourth instar larvae, old pupae, sucrose-fed adults and total genomic DNA extracted from dissected fourth instar larval and sucrose-fed adult midguts was hybridized to the four bacterial probes (Figure 2A). Different amounts of bacterial cells were present in the different A. aegypti samples (Table 1). Asaia sp., Klebsiella sp. and Serratia $s p$. were present in amounts of $>10^{5}$ and $<6 \times$ $10^{5}$ cells in whole larvae, old pupae and adults and in larval midguts, with the exception of one whole larva (L2) and one pupa (P2), in which amounts $<10^{5}$ cells of both Asaia sp. and Klebsiella sp. cells were detected (Table 1). The detection of Asaia sp. and Serratia sp. in larvae, pupae and adults of $A$. aegypti is consistent with previous studies that showed strong interactions between these bacteria and mosquito species $[1,10,11]$. In addition, even though a statistical analysis could not be performed due to the small number of samples investigated, our experiments suggest the presence of generally higher amounts of cells in $A$. aegypti larvae (whole larva L1; midguts L1 and L2) as compared to whole pupae (Figure $2 \mathrm{~A}$ and Table 1). These results corroborate with other studies showing a reduction in bacterial numbers after the transition from the last feeding larval stage to the pupal stage [12]. On the other hand, lower amounts $\left(<10^{5}\right.$ cells $)$ of

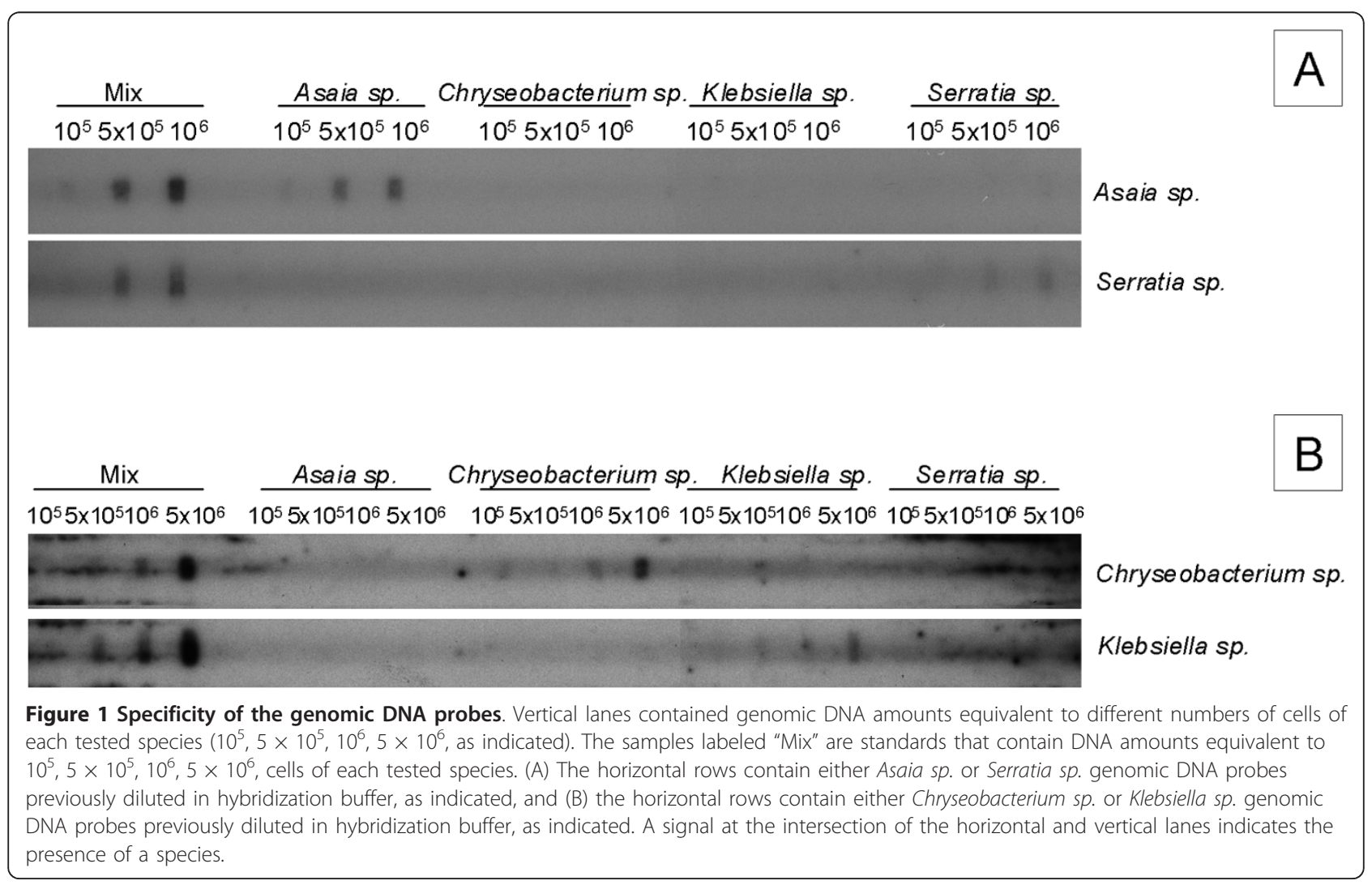




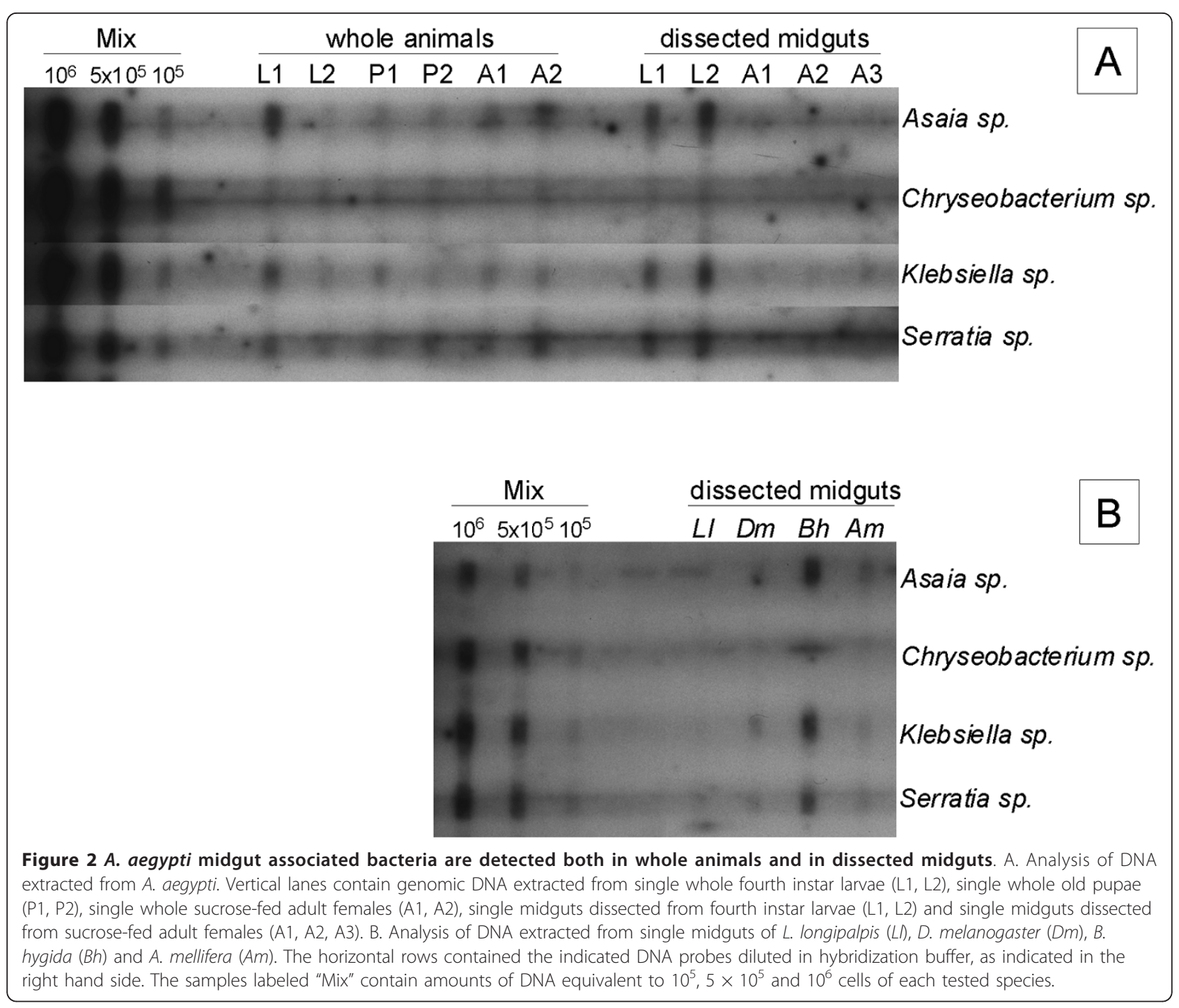

Chryseobacterium sp. cells were detected in whole larvae, pupae, adults and in larval midguts. These results might explain why this bacterial genus has not been identified in A. aegypti [1,2], despite its high prevalence in Anopheles gambiae [13]. Finally, in adult midguts the investigated species were either not detected or detected at counts $<10^{5}$ (Table 1). The higher number of bacterial cells detected in whole adults as compared to that observed in adult midguts could be attributed to bacterial colonization of other $A$. aegypti tissues as has been demonstrated for both A. aegypti and Anopheles stephensi $[10,14]$.

Our results show that the checkerboard DNA-DNA hybridization technique can be employed to detect the presence of bacterial species known to be associated with $A$. aegypti in $A$. aegypti samples. This technique reveals differences in the counts of bacteria present in distinct life stages and is sensitive enough to detect differences in the amount of bacterial cells amongst individual samples [for example, Figure 2A, whole larvae (L1 and L2) hybridized to the Asaia sp. probe]. Overall, our results demonstrate that the checkerboard DNA-DNA hybridization is a suitable technique for routine investigation of mosquito samples.

The presence of these four bacterial species was also investigated in midguts dissected from another insect vector, Lutzomyia longipalpis, and from three other insect species Drosophila melanogaster, Bradysia hygida and Apis mellifera (Figure 2B, Table 1). Klebsiella sp. and Serratia $s p$. were both detected in all four insect species tested. Asaia sp. cells were detected in D. melanogaster, A. mellifera and B. hygida. Chryseobacterium sp. was the only bacterial species not detected in this group of insects. Klebsiella $s p$. and Serratia $s p$. have been 
Table 1 Estimated numbers of bacterial cells in whole animals and dissected midguts

\begin{tabular}{|c|c|c|c|c|}
\hline Insect samples & Asaia sp. & Chryseobacterium sp. & Klebsiella sp. & Serratia sp. \\
\hline A. aegypti L1 (w) & $5.7 \times 10^{5}$ & $<10^{5}$ & $3.2 \times 10^{5}$ & $1.8 \times 10^{5}$ \\
\hline A. aegypti L2 (w) & $<10^{5}$ & $<10^{5}$ & $<10^{5}$ & $1.1 \times 10^{5}$ \\
\hline A. aegypti P1 (w) & $1.6 \times 10^{5}$ & $<10^{5}$ & $1.4 \times 10^{5}$ & $1.5 \times 10^{5}$ \\
\hline A. aegypti P2 (w) & $<10^{5}$ & $<10^{5}$ & $<10^{5}$ & $1.5 \times 10^{5}$ \\
\hline A. aegypti $\mathrm{A} 1(\mathrm{w})$ & $2.5 \times 10^{5}$ & $<10^{5}$ & $1.2 \times 10^{5}$ & $1.8 \times 10^{5}$ \\
\hline A. aegypti A2 (w) & $3.4 \times 10^{5}$ & $<10^{5}$ & $1.4 \times 10^{5}$ & $3.1 \times 10^{5}$ \\
\hline A. aegypti L1 (mg) & $3.0 \times 10^{5}$ & $<10^{5}$ & $2.8 \times 10^{5}$ & $2.0 \times 10^{5}$ \\
\hline A. aegypti L2 (mg) & $5.1 \times 10^{5}$ & $<10^{5}$ & $4.4 \times 10^{5}$ & $2.9 \times 10^{5}$ \\
\hline A. aegypti A1 (mg) & $<10^{5}$ & $<10^{5}$ & $<10^{5}$ & N.D. \\
\hline A. aegypti A2 (mg) & N.D. & N.D. & $<10^{5}$ & $<10^{5}$ \\
\hline A. aegypti A3 (mg) & N.D. & N.D. & $<10^{5}$ & N.D. \\
\hline L. longipalpis (mg) & N.D. & N.D. & $<10^{5}$ & $<10^{5}$ \\
\hline D. melanogaster (mg) & $<10^{5}$ & N.D. & $2.1 \times 10^{5}$ & $<10^{5}$ \\
\hline B. hygida (mg) & $1.4 \times 10^{6}$ & N.D. & $8.1 \times 10^{5}$ & $7.2 \times 10^{5}$ \\
\hline A. mellifera (mg) & $3.1 \times 10^{5}$ & N.D. & $1.6 \times 10^{5}$ & $<10^{5}$ \\
\hline
\end{tabular}

The images shown in Figure 2 were digitized and the numbers of bacterial cells in individual whole A. aegypti and dissected insect midguts of $A$. aegypti, Lutzomyia longipalpis, Drosophila melanogaster, Bradysia hygida and Apis mellifera were estimated using the Image-Quant TL software (GE Healthcare UK), as described in Additional file 1.

w, whole individual; mg, midgut; ND, not detected.

previously reported in D. melanogaster, A. mellifera and L. longipalpis [15-18]. In addition, our results revealed the presence of $A$. aegypti midgut-associated bacteria species in the midgut of $B$. hygida, an insect species in which the indigenous microbiota has not previously been characterized.

The use of the checkerboard DNA-DNA hybridization technique to detect and estimate bacteria from insects is appealing since it can contribute to the characterization of insect microbiota without the need of employing culture dependent methods that are both laborious and time consuming. Sample preparation is simple, which enables the rapid and simultaneous investigation of numerous samples collected from distinct populations. In addition, this method has the sensitivity to detect bacteria in single individuals at different developmental stages (larval, pupal), as well as in a single organ such as the midgut, and therefore, can be employed to determine if there are differences amongst individuals in a single population. Finally, the use of this technique can contribute to the characterization of the microbial ecology associated with mosquitoes, elucidate intrinsic and extrinsic factors that influence bacterial composition and identify the bacteria that are implicated in vectorial capacity differences between mosquito populations.

\section{Additional material}

Additional file 1: Experimental procedures. The file provides a detailed description of the experimental procedures employed.

\section{Acknowledgements}

We thank Dr. Jorge Cury de Almeida for providing B. hygida specimens, Dra. Zilá Luz Paulino Simões for providing A. mellifera specimens, Dra. Maria H. de S. Goldman (FFCLRP-USP) for nucleotide sequencing, Telma Ferreira Costa Aguiar for technical assistance and Dr. Richard J. Ward for helpful comments on the manuscript. This work was funded by the following grants: INCT Entomologia Molecular and MCT/CNPq (FJAL and PFPP), FAPERJ (FJAL), FAPESP (NM), FAPEMIG and FIOCRUZ (PFPP).

\section{Author details}

'Laboratório de Biotecnologia, Universidade Estadual do Norte FluminenseUENF, Av. Alberto Lamego 2000, Horto, 28013-602, Campos dos Goytacazes, RJ, Brazil. '2Departamento de Materiais Dentários e Prótese, Faculdade de Odontologia de Ribeirão Preto - USP, Av. do Café, s/n, Monte Alegre, 14040904, Ribeirão Preto, SP, Brazil. ${ }^{3}$ Laboratório de Entomologia Médica, Centro de Pesquisas René Rachou, Fundação Oswaldo Cruz, Av. Augusto de Lima 1715, 30190-002, Barro Preto, Belo Horizonte, MG, Brazil. ${ }^{4}$ Departamento de Análises Clínicas, Toxicológicas e Bromatológicas, Faculdade de Ciências Farmacêuticas de Ribeirão Preto - USP, Av. do Café s/n, Monte Alegre, 14040-903, Ribeirão Preto, SP, Brazil.

\section{Authors' contributions}

AOG, RCCG, NS and NM performed the experiments. AOG and CN performed the quantification of the results. FJAL, PFPP and NM designed the study and drafted the manuscript. All authors read and approved the final manuscript.

\section{Competing interests}

The authors declare that they have no competing interests.

Received: 22 September 2011 Accepted: 20 December 2011 Published: 20 December 2011

\section{References}

1. Gusmao DS, Santos AV, Marini DC, Bacci M Jr, Berbert-Molina MA, Lemos FJ: Culture-dependent and culture-independent characterization of microorganisms associated with Aedes aegypti (Diptera: Culicidae) (L.) and dynamics of bacterial colonization in the midgut. Acta trop 2010, 115:275-281.

2. Gusmão DS, Santos AV, Marini DC, Russo ES, Peixoto AMD, Bacci MJ, Berbert-Molina MA, Lemos FJA: First isolation of microorganisms from the gut diverticulum of Aedes aegypti (Diptera: Culicidae): new perspectives 
for an insect-bacteria association. Mem Inst Oswaldo Cruz 2007, 102:919-924.

3. Terenius $\mathrm{O}$, de Oliveira CD, Pinheiro WD, Tadei WP, James AA, Marinotti O: 16S rRNA gene sequences from bacteria associated with adult Anopheles darlingi (Diptera: Culicidae) mosquitoes. J Med Entomol 2008, 45:172-175.

4. Spratt DA: Significance of bacterial identification by molecular biology methods. Endodont Top 2004, 9:5-14.

5. do Nascimento C, Santos Barbosa RE, Mardegan Issa JP, Watanabe E, Yoko Ito I, Monesi N, Albuquerque Junior RF: The use of fluorescein for labeling genomic probes in the checkerboard DNA-DNA hybridization method. Microbiol Res 2008, 163:403-407.

6. Papaioannou W, Gizani S, Haffajee AD, Quirynen M, Mamai-Homata E, Papagiannoulis L: The microbiota on different oral surfaces in healthy children. Oral Microbiol Immunol 2009, 24:183-189.

7. Sakamoto M, Siqueira JF Jr, Rocas IN, Benno Y: Diversity of spirochetes in endodontic infections. J Clin Microbiol 2009, 47:1352-1357.

8. Socransky SS, Smith C, Martin L, Paster BJ, Dewhirst FE, Levin AE: "Checkerboard" DNA-DNA hybridization. Biotechniques 1994, 17:788-792.

9. do Nascimento C, de Albuquerque RF Jr, Monesi N, Candido-Silva JA: Alternative method for direct DNA probe labeling and detection using the checkerboard hybridization format. J Clin Microbiol 2010, 48:3039-3040

10. Crotti E, Damiani C, Pajoro M, Gonella E, Rizzi A, Ricci I, Negri I, Scuppa P, Rossi P, Ballarini P, et al: Asaia, a versatile acetic acid bacterial symbiont, capable of cross-colonizing insects of phylogenetically distant genera and orders. Environm Microbiol 2009, 11:3252-3264.

11. Gaio Ade O, Gusmao DS, Santos AV, Berbert-Molina MA, Pimenta PF, Lemos FJ: Contribution of midgut bacteria to blood digestion and egg production in Aedes aegypti (diptera: culicidae) (L.). Parasit Vectors 2011, 4:105

12. Moll RM, Romoser WS, Modrzakowski MC, Moncayo AC, Lerdthusnee K: Meconial peritrophic membranes and the fate of midgut bacteria during mosquito (Diptera: Culicidae) metamorphosis. J Med Entomol 2001, 38:29-32.

13. Dong Y, Manfredini F, Dimopoulos G: Implication of the mosquito midgut microbiota in the defense against malaria parasites. PLoS Pathog 2009, 5: e1000423.

14. Favia G, Ricci I, Damiani C, Raddadi N, Crotti E, Marzorati M, Rizzi A, Urso R, Brusetti L, Borin S, et al: Bacteria of the genus Asaia stably associate with Anopheles stephensi, an Asian malarial mosquito vector. PNAS 2007, 104:9047-9051.

15. Carina Audisio M, Torres MJ, Sabate DC, Ibarguren C, Apella MC: Properties of different lactic acid bacteria isolated from Apis mellifera $\mathrm{L}$. bee-gut. Microbiol Res 2011, 166:1-13.

16. Cox CR, Gilmore MS: Native microbial colonization of Drosophila melanogaster and its use as a model of Enterococcus faecalis pathogenesis. Infect Immun 2007, 75:1565-1576.

17. Gouveia C, Asensi MD, Zahner V, Rangel EF, Oliveira SM: Study on the bacterial midgut microbiota associated to different Brazilian populations of Lutzomyia longipalpis (Lutz \& Neiva) (Diptera: Psychodidae). Neotrop Entomol 2008, 37:597-601.

18. Mrázek J, Strosová L, Fliegerová K, Kott T, Kopecný J: Diversity of insect intestinal microflora. Folia Microbiol 2008, 53:229-233.

doi:10.1186/1756-3305-4-237

Cite this article as: Gaio et al:: Use of the checkerboard DNA-DNA hybridization technique for bacteria detection in Aedes aegypti (Diptera: Culicidae) (L.). Parasites \& Vectors 2011 4:237.

\section{Submit your next manuscript to BioMed Central and take full advantage of:}

- Convenient online submission

- Thorough peer review

- No space constraints or color figure charges

- Immediate publication on acceptance

- Inclusion in PubMed, CAS, Scopus and Google Scholar

- Research which is freely available for redistribution

Submit your manuscript at www.biomedcentral.com/submit
Ciomed Central 